\title{
CURRENT JUDICIAL REFORM IN UKRAINE AND IN POLAND: ONSTITUTIONAL AND EUROPEAN LEGAL ASPECT IN THE CONTEXT OF INDEPENDENT JUDICIARY
}

\author{
Grzegorz Borkowski, \\ Doctor of Law, Judge seconded to the Regional Court \\ Warszawa-Praga, former Head of Office of the National \\ Council of Judiciary (Poland) \\ Olga Sovgyria, \\ Doctor of Science (Law), professor \\ of the Department of Constitutional Law, \\ Taras Shevchenko National University of Kyiv (Kyiv, Ukraine)
}

https://doi.org/10.33327/AJEE-18-2.3-a000011

Summary: 1. Introduction. - 2. The Judicial System of Poland at the Present Stage. - 2.1. Constitutional Tribunal. - 2.1.1. Composition of the Constitutional Tribunal. - 2.1.2. Refusal of Publication of Certain Judgments of the Constitutional Tribunal. - 2.2. The Common Courts System. - 2.2.1. Merger of the Functions of Minister of Justice and Prosecutor General and its Consequences. - 2.2.2. Court directors. 2.2.3. Random Allocation of Cases. - 2.2.4. Judicial Appointments. - 2.2.5. Secondment of Judges. - 2.2.6. Appointment and Dismissal of Court Presidents. - 2.3. Supreme Court. - 2.3.1. Extraordinary Complaint (Article 86). - 2.3.2. Changes in the Structure of the Supreme Court. - 2.3.3. Lay Judges. - 2.3.4. Changes in Disciplinary Proceedings in Respect of the SC and the Common Judiciary. - 2.4. National Council for Judiciary. 2.4.1. Entrusting the Sejm with the Competence to Elect the Members of the Council. 2.4.2 Termination of Office of the Current Members of the Council. - 3. Judicial Reform in Ukraine in 2016: Problems of Implementation. - 3.1. General Characteristics of the Judiciary in Ukraine. - 3.2. Status of the Constitutional Court of Ukraine: Main Innovations. - 3.2.1. Statutory Aspect of the Independence of the Constitutional Court of Ukraine. - 3.2.2. Functional Aspect of the Independence of the Constitutional Court of Ukraine. - 3.2.3. Financial Aspect of the Independence of the Constitutional Court of Ukraine. - 3.3. Status of the Supreme Court and Courts. - 3.3.1. Statutory Aspect of the Independence of the Supreme Court and Courts of General Jurisdiction. - 3.3.2. Functional Aspect of the Independence of the Supreme Court and Courts of General Jurisdiction. 3.4. Status of the High Council of Justice. - 3.4.1. Statutory Aspect of the Independence of the High Council of Justice. - 4. Concluding Remarks. 
Since the Revolution of Dignity in 2014, Ukraine has been carrying out revision and bringing to conformity with international standards of legislation in terms of judicial system and legal procedure. On 2 June, 2016 the law amending the Constitution of Ukraine in the part of justice, as well as the Law of Ukraine 'On Judicial System and Status of Judges' was adopted. On 13 July, 2017 a new Law of Ukraine 'On the Constitutional Court of Ukraine' was adopted. In the middle of December 2017, the election to the Supreme Court finished and its new composition was formed, at the same time the revision of all procedural codes took place. However, one of the main problems of the judiciary in Ukraine has been the problem of the judicial independence as a whole and in the part of independence of judges. The subject of this research is the question of judicial independence in the context of respective international standards.

Similarly, the aim of part of the paper about the judicial system of Poland is to show the legislative changes regarding the judiciary which took place in Poland recently, i.e. within the last 3 years. As the ongoing changes of functioning, competence and organization of the Constitutional Tribunal, common courts, the Supreme Court and the National Council of Judiciary have been observed and commented upon by various European institutions, they will be shown in relation to the common European standards regarding the judicial independence presented in opinions and reports of Venice Commission, European Network of Councils of Judiciary and Consultative Council of European Judges.

Keywords: Judicial System of Poland and of Ukraine, Judicial Reform, European Standards of Justice.

\section{INTRODUCTION}

The axiom of modern constitutionalism is that the independence of judges and the judicial system as a whole is the first and most important guarantee of the right to a fair trial, which is guaranteed by the European Convention on Human Rights of $1950 .{ }^{1}$ According to paragraphs 2 and 3 of Magna Carta of Judges (Fundamental Principles), ${ }^{2}$ judicial independence and impartiality are essential prerequisites for the operation of justice. Judicial independence shall be statutory, functional and financial. Recommendation № 94 (12) emphasizes (in the first sentence of Principle 1.2) that 'the independence of judges should be guaranteed pursuant to the provisions of the Convention [for the Protection of Human Rights and Fundamental Freedoms] and constitutional principles, for example by inserting specific provisions in the constitutions or other legislation or incorporating the provisions of this recommendation in internal law. ${ }^{3}$ Thus, we try to

1 The European Convention on Human Rights and Fundamental Freedoms of 04 November 1950, ratified by Ukraine with reservations on 17 July 1997 < https://www.echr.coe.int/Documents/Convention_ ENG.pdf> accessed 4 May 2019.

2 Magna Carta of Judges (Fundamental Principles), Consultative Council of European Judges (CCJE), 17 November 2010, Strasbourg <http://www.vru.gov.ua/content/file/Opinion_1-18.pdf > accessed 4 May 2019.

3 Opinion No. 1 (2001) of the CCJE for the attention of the Committee of Ministers of the Council of Europe (CMCE) on standards concerning the independence of the judiciary and the irremovability of judges (Recommendation No. R (94) 12 on the independence, efficiency and role of judges and the relevance of its standards and any other international standards to current problems in these fields), 23 November 2001, Strasbourg <http://www.vru.gov.ua/content/file/Opinion_1-18.pdf> accessed 4 May 2019. 
show the state of the legislative regulation and the problem of the realization of the principle of independent modern judicial system of Poland, basing on the European standards presented by different international bodies, whereas of Ukraine on the basis of the abovementioned criteria: statutory, functional and financial.

The methodology of this study is of complex nature and includes dialectic, comparative, legal, systemic, logical, formal, structural and functional methods of scientific research.

In order to establish the limits of this research, it should be noted that the functioning of courts of general jurisdiction is the subject of constitutional and legal regulation only in general terms, since these issues are regulated by the norms of the respective branches of law. The subject of constitutional law are the norms that establish the foundations of the system of these bodies, the order of their formation, the key powers. Similarly, the European standards relate to general issues regarding the functioning of the judicial system and guarantees of judicial independence, leaving the margin of appreciation to the Member States. We will consider this issue in the publication on the basis of this approach.

\section{THE JUDICIAL SYSTEM OF POLAND AT THE PRESENT STAGE}

\subsection{CONSTITUTIONAL TRIBUNAL}

The first change in the legal system introduced in the course of the last three years, which needs to be shown not only with legal, but also with the factual background, is the reform of the Constitutional Court. The following issues will be discussed below:

1. Changing the composition of the Tribunal;

2. Refusal of publication of certain judgments of the Constitutional Tribunal;

3. Status of CT justices.

\subsubsection{Composition of the Constitutional Tribunal}

Constitutional Tribunal consists of 15 judges elected by Sejm (lower chamber of the Polish Parliament). On 8 October 2015 when three new Constitutional Tribunal judges were elected to replace those judges whose mandates were about to expire in November 2015, the Sejm- on the basis of Act of 25 June $2015^{4}$ - appointed two additional judges ahead of time in order to replace two justices whose mandates would not actually have ended until December and whose successors, in light of applicable law, should have been selected during the next term of Parliament, which started on 12 November 2015. After the 2015 parliamentary election, new majority contested the election of not only two, but all the five judges of the Constitutional Tribunal (hereinafter - CT) elected on 8 October 2015 by the previous Sejm. On 25 November 2015 Sejm adopted resolutions invalidating the election of judges of the Constitutional Tribunal by the previous Sejm; on 9 December 2015 the Constitutional Tribunal found some of the provisions of Act of 25 June 2015 to be unconstitutional, thus invalidating the election of the two additional judges. At the same time, the Tribunal ruled that the election of the other three judges 
by the previous Sejm had been constitutional and the Polish President was required to swear them in, which is a pre-condition for judges to start their service in the Tribunal. Nevertheless, they were not allowed to take up their duties, due to the refusal of the President of the Republic to accept their oaths. ${ }^{5}$ On 19 December 2016, the President of the Republic signed the three new laws concerning the Tribunal and on the very same day, the President of the Republic appointed a judge, elected by the new Sejm, to the position of 'acting President' of the Constitutional Tribunal (a figure unknown to the Polish Constitution). The next day, on 20 December 2016, she admitted the three judges, nominated by the 8 th term of the Sejm, to take up their function in the Tribunal and convened a meeting of the General Assembly for the same day. In spite of the fact that one judge was unable to participate and requested to postpone the meeting for the next day, judge Julia Przyłębska, as an "acting president" refused and, as a result to that approach, seven other judges also did not participate in the meeting. Only six judges, including the three, who had been unlawfully - according to the judgment of the CT nominated, took part in the meeting and elected two persons, who were presented as candidates to the President of the Republic. One day later, i.e. on 21 December 2016, the President of the Republic appointed one of them, judge Julia Przyłębska, as a President of the Constitutional Tribunal.

As a consequence, in view of National Council of Judiciary, as well as many constitutionalists, the current composition of the CT (i.e. including the three judges elected for already occupied positions) raises issues as to the validity of its judgments and the principle of legal certainty. As a result, since the beginning of this constitutional crisis, the number of legal questions posed by ordinary courts to the CT has drastically decreased and many institutions, such as the National Council of the Judiciary, have decided not to address $\mathrm{CT}$ with legal questions.

The current system of election of CT judges was widely criticized. As stated by the Venice Commission in its opinion of $2016,{ }^{6}$ 'A ruling party should not be in a position to have all judges appointed to its liking. (...) It must be stressed that under the current Constitution of Poland of 1997 judges of the CC are elected by the Sejm by a simple majority, which, in a situation where one party has a majority, creates a risk of politicisation of these elections. The Venice Commission recommended that the Constitution be amended in the long run to introduce a qualified majority for the election of the Constitutional Tribunal judges by the Sejm, combined with an effective anti-deadlock mechanism. Due to the constitutional crisis in Poland, the European Commission triggered, for the first time, its new mechanism under the 'Rule of Law Framework' and, in its Recommendations of 27 July 2016 and 21 December 2016, it found that there was a 'systemic threat to the rule of law (...) as the composition of Parliament changes after elections, the new Parliament must not be deprived of its power to take its own decisions on issues that arise during its mandate. It would be in conflict with democratic principles if Parliament could choose public officials including

$5 \quad$ See: T T Koncewicz, 'Of institutions, democracy, constitutional self-defence and the rule of law: The Judgments of the Polish Constitutional Tribunal in Cases K 34/15, K 35/15 and beyond' (2016) 53 (6) Common Market Law Review 1753.

6 Venice Commission, Opinion on the Amendments to the Act of 25 June 2015 of the Constitutional Tribunal of Poland, adopted at its 106th plenary session on 11-12 March 2016, CDL-AD(2016)001 and Poland. Opinion on the Act on the Constitutional Tribunal, adopted at its 108e session on 14-15 October 2016, CDL-AD(2016)026, p. 21. 
judges (far) in advance even if the term of office expires within the term of office of the subsequent term of Parliament. Vice versa, the subsequent Parliament has to respect the decisions of the former Parliament with regard to appointments of public officials.' In this regard, one of the main European Commission demands was to implement fully the judgments of the Constitutional Tribunal of 3 and 9 December 2015 which requires that the three judges that were lawfully nominated in October 2015 by the previous legislature can take up their function of judge in the Constitutional Tribunal, and that the three judges nominated by the new legislature without a valid legal basis do not take up the post of judge without being validly elected; for this reason, the President of the Republic is required to urgently take the oath of the three judges elected by the previous legislature'.

\subsubsection{Refusal of Publication of Certain Judgments of the Constitutional Tribunal}

Between December 2015 and August 2016, a number of Constitutional Tribunal rulings were not published. The judgments of 9 March 2016 and of 11 August 2016 were not published by the Government. The prompt and undisturbed promulgation of judicial decisions is one of the prerequisites of judicial independence, which is in turn one of the pillars of separation of powers. This point was raised by in the point 8 of the Concluding Observations of the UN Human Rights Committee of 31 October 2016 on the seventh periodic report of Poland:

'The State party should ensure respect for and protection of the integrity and independence of the Constitutional Tribunal and its judges and ensure the implementation of all its judgments. The Committee urges the State party to immediately publish officially all the judgments of the Tribunal; refrain from introducing measures that obstruct its effective functioning and ensure a transparent and impartial process for the appointment of its members and security of tenure, which meets all requirements of legality under domestic and international law.' The European Commission demanded from Polish government to: publish and implement fully the judgments of the Constitutional Tribunal of 9 March 2016 and the judgment of 11 August 2016 concerning the law of 22 July 2016 on the Constitutional Tribunal and other judgments rendered after that date and future judgments; ensure that any reform of the law on the Constitutional Tribunal respects the judgments of the Constitutional Tribunal, takes the Opinions of the Venice Commission fully into account and ensures that the effectiveness of the Constitutional Tribunal as a guarantor of the Constitution is not undermined.

As underlined by the Venice Commission in March 2016: ${ }^{9}$

'Decisions of a constitutional court which are binding under national constitutional law must be respected by other political organs; this is a European and international standard that is fundamental to the separation of powers, judicial independence, and the proper functioning of the rule of law. This is particularly valid in the case of the decision of the Tribunal on the nomination of new judges in October/December 2015. The Constitutional

\footnotetext{
$7 \quad$ Ibidem, 114.

8 This document is available in English at <www.tbinternet.ohchr.org > accessed 4 May 2019.

9 Venice Commission, 'Opinion no. 833/2015 of 11 March 2016 On amendments to the Act of 25 June 2015 on the Constitutional Tribunal' CDL-AD(2016)001.
} 
Tribunal decided that the election of those judges, whose vacancy opened up in December 2015, i.e. after the new Sejm has resumed work, was not a competence of the old Sejm. This verdict has to be respected by the old government, now the opposition. The election of these judges by the 8th Sejm had a constitutional basis. On the other hand, the election of the judges who occupy a position that opened up during the mandate of the 7th Sejm has a constitutional basis as well and the new Sejm has to respect that election.'

\subsubsection{Status of Tribunal's Justices}

Most of the provisions related to the status of judges were introduced by the Act on the status of judges of the Constitutional Tribunal of 30 November 2016. On 15 September 2017, the aforementioned act was amended, mainly in regard of qualifications for the office of the Justice of Constitutional Tribunal. So far, to become a judge of the Tribunal, one had to be a person with a profound legal knowledge and meeting the requirements necessary to perform the office of a judge of the Supreme Court. After the changes, in order to become a judge of the Constitutional Tribunal, it is sufficient to meet the requirements necessary to apply for the position of the Supreme Administrative Court judge. The difference is that previously, at least a ten-year service as a judge, prosecutor, counsellor of the State Treasury Office or the profession of lawyer, legal counsel or notary in Poland was obligatory, while now it became sufficient to have worked in public institutions in positions related to the application or creation of administration law (which includes, for instance, the parliament). What is more, in exceptional cases, the President, at the request of the National Council of the Judiciary, may appoint a candidate with a shorter period of employment. Needless to say, lowering the requirements towards the justices of the constitutional court will not help in building the trust of the society towards the judiciary.

\subsection{THE COMMON COURTS SYSTEM}

In this section, the following legislative changes which have been introduced since 2015 will be discussed:

1) Merger of the functions of Minister of Justice and Prosecutor General;

2) Changes in administrative and financial activity of courts;

3) Random allocation of cases;

4) New practices in appointment of Judges;

5) Changes concerning secondment of Judges;

6) New procedure of appointment and dismissal of Court Presidents.

\subsubsection{Merger of the Functions of Minister of Justice and Prosecutor General and its Consequences}

In Poland the personal union of Minister of Justice (hereinafter - MoJ) and the Prosecutor General has been reintroduced. These two offices were merged by the 2016 Act on Public Prosecutor's Office. ${ }^{10}$ That marks the return to the legal status from 31 March 2010.

$10 \quad$ Act of 28 January 2016 on the Prosecution Office. 
This time, however, the power of the MoJ is broader and it determines MoJ's position within the judicial system: $\mathrm{MoJ}$ is interested in the court proceedings as the superior of all prosecutors, and, at the same time, has important powers vis-à-vis the courts and individual judges. The merger of the function also has its additional consequences with regard to disciplining of judges. The law amending the Law on Common Courts System, which entered into force on 12 August 2017, contains provisions aimed at disciplining judges, mainly related to the creation of disciplinary chamber in the Supreme Court. In addition, the Disciplinary Officer for judges of common courts and his two deputies are appointed for a 4-year term by the Minister of Justice (and not, as previously, the National Council of the Judiciary).

When the Supreme Court Disciplinary Officer (or the Ministerial Officer) refuses to institute disciplinary proceedings because he or she believes that there are no sufficient grounds to do so, a copy of the decision refusing to institute proceedings must be delivered to the Minister of Justice/General Public Prosecutor, who is entitled to raise an objection; then the Disciplinary Officer is obliged to institute disciplinary proceedings. The Minister's instructions concerning the further course of proceedings shall be binding on the respective Disciplinary Officer.

The recommendation of the Committee of Ministers of the Council of Europe to Member States on the independence, efficiency and role of judges ${ }^{11}$ indicates that the governments of the Member States should strive to implement the necessary measures to provide judges with training, status, position and remuneration corresponding to the gravity and dignity of the office and the scope of responsibility resting upon them. Assigning duties relating to the judiciary to other bodies, i.e. to the Minister of Justice, results in granting him the excessive power to supervise the administrative activities of courts. New provisions concerning the organisation of judicial disciplinary responsibility also contradict the European standards. Appointment of the prosecuting organ by the Minister of Justice and the interference of $\mathrm{MoJ}$ in the disciplinary proceeding at the level of the Supreme Court goes against the ENCJ recommendations from the 2015 Report, ${ }^{12}$ whose conclusions state: 'There should be a separate body responsible for receiving complaints and the administration of them, independent of the Ministry of Justice and responsible only to the Judiciary.(...)' as well as 'There is also an obvious need for caution in the recognition of disciplinary liability of judges, which is based in the requirement to maintain judicial independence and freedom from any undue pressure exercised by other state branches of power'.

\subsubsection{Court directors}

Court directors, responsible for administrative and financial activity of the court, have become the superiors of all court staff with only judges remaining outside their scope of competence. The dependence of directors from the MoJ has been augmented by the changes introduced in March 2017 amendments to the Act on common courts system, abolishing transparent competition procedures in their appointment process. From May 2017 on, it is solely the Minister of Justice who can appoint and dismiss the

11 Recommendation Rec No. R(94)12 (p. 4).

12 Report on Minimum Judicial Standards V - Disciplinary proceedings and liability of judges. 
court directors at his discretion, without any role of court presidents. ${ }^{13}$ Combining the functions of the Minister of Justice and Public Prosecutor General leads to a situation where external administrative supervision over common courts is exercised by a body also acting as public prosecutor before courts in criminal cases (empowered also to institute and participate in civil, as well as employment and social security proceedings). According to the National Council of Judiciary the above duality of tasks and duties resting with the Minister of Justice - Public Prosecutor General - poses a serious threat to the independence of the courts.

As stated in Venice Commission Opinion of 11 December 2017 'the mechanisms of accountability should not interfere with the independence of the judges, and of the bodies of judicial governance. The judiciary should be insulated from quickly changing political winds. The courts often have to adjudicate on conflicts between individual rights and the State, and that relationship is imperilled when the State takes over the control of judicial functions. The provisions enable the legislative and executive powers to interfere in a severe and extensive manner in the administration of justice, and thereby pose a grave threat to the judicial independence as a key element of the rule of law. ${ }^{14}$

\subsubsection{Random Allocation of Cases}

The mechanism of random allocation of cases as a general rule in the common courts has been introduced by the Act 12 July 2017 on amendments to the Act - Law on Common Courts System.

The introduction of electronic system of random allocation of cases can be in general assessed positively, although the system in force so far (where the allocation of cases was done in accordance with the alphabetical and numerical system, as the decision on the allocation of a case to a given judge was, in principle, determined by the order of the cases incoming) did not require an immediate change. It was in accordance with Recommendation Rec (94) $12^{15}$ of the Committee of Ministers on the independence, efficiency and role of judges (repeated in similar form in the Recommendation $\mathrm{CM} / \mathrm{Rec}$ (2010) 12 of the Committee of Ministers to member states on judges: independence, efficiency and responsibilities): 'The distribution of cases should not be influenced by the wishes of any party to a case or any person concerned with the results of the case. Such distribution may, for instance, be made by drawing of lots or a system for automatic distribution according to alphabetic order or some similar system. The ENCJ standards set out in Distillation report of $2016^{16}$ and - in a more detailed manner in the 2014 Report 'Minimum Judicial Standards IV - Allocation of Cases'17 are in general met by these solutions, as in particular: 'Individual cases should be assigned

13 Changes introduced by Art. 1 point 4 c) of the Act of 23 March 2017 amending the Act on the system of common courts (Journal of Laws [2017] item 803), which entered into force on 4 May 2017.

14 See Venice Commission, 'Opinion No. 904 / 2017', 11 December 2017, P. 128.

15 Recommendation Rec No (94)12, Principle I, point 2 e).

16 European Network of Councils for the Judiciary, 'Distillation of ENCJ Principles, Recommendations and Guidelines 2004-2016’ (p 11, pts 65-67) < http://www.ejtn.eu/Documents/encj_distillation_ report_2004_2016.pdf> accessed 4 May 2019.

17 Eleven standards set out in European Network of Councils for the Judiciary, 'Minimum Judicial Standards IV' (ENCJ Report 2013-14) 8-10. 
to individual judges by a mechanism that safeguards the independence of the judiciary and excludes the possibility of any pre-determination of the decision. There should be an established and publicly available method of allocation of cases, governed by statute, regulation or judicial or administrative practice. (...) The following criteria should be paramount: the right to a fair trial; the independence of the Judiciary; the legality of the procedure; the nature and complexity of the case; the competence, experience and specialism of the Judge; the availability and/or workload of the Judge; the impartiality of the Judge; the public perception of the independence and impartiality of the allocation". It should be noted, however, that random allocation system does not pertain to the Supreme Court, where the Presidents of chambers have too much discretion in setting up panels, as raised by the Venice Commission: ${ }^{18}$ 'In particular, the First President/ Presidents of Chambers should not have an unlimited discretion in setting up panels, distributing cases amongst them and assigning judges (and lay judges) to the benches. Also, the methods of electronic allocation of cases are set up at the discretion of the MoJ, which was criticized by the Venice Commision: 'However, in the Rules of Procedure the MoJ is competent to set 'detailed rules on the assignment of cases' and the 'method of random allocation of cases', and may also fix special rules where the random allocation of cases is impossible or inefficient. If there are to be exceptions to the general principle of random allocation of cases, they should be clearly and narrowly formulated in the law. Setting of the method of distribution of cases should not be within the discretionary power of the MoJ..$^{19}$ Nevertheless, the very idea of the random allocation of cases is not controversial, as long as the introduction of such a system is prepared in detailed way and the system does not allow the administrative power to have any influence on it.

\subsubsection{Judicial Appointments}

The practical application of existing law has also undergone certain changes in recent years. On 29 June 2016, the President of the Republic of Poland refused to appoint 10 judges presented by the National Council of the Judiciary of Poland with a motion for appointment.

The CCJE Bureau in its comments on 26 October 2016 emphasised that it considered that the decision of the President not to appoint as judges ten candidates presented by the National Council of the Judiciary was not in accordance with the CoE standards for judicial independence. The President of Poland should have followed the National Council's advice by appointing the nominated candidates as judges. $\mathrm{He}$ did not provide reasons for the decision not to appoint, and such lack of transparency in the procedure was not in line with the Council of Europe standards for judicial independence. ${ }^{20}$ The Venice Commission in its Report on the Judicial Appointments stated that 'a judicial council should have a decisive influence on the appointment and promotion of judges ${ }^{321}$.

\footnotetext{
18 Venice Commission, 'Opinion No 904 / 2017', 11 December 2017, CDL-AD (2017) 031, P. 19 (\$ 88).

19 Ibidem, $\$ 120$.

20 See CCJE Bureau, 'Report on judicial independence and impartiality in the Council of Europe member States in 2017' Strasburg, 7 February 2018, CCJE-BU (2017) 11.

21 CCJE, 'Opinion No 403 on Judicial Appointments', 22 June 2007, P. 6 (\$25).
} 


\subsubsection{Secondment of Judges}

The secondment of judges to the higher tier court has now become easier. The practice shows that some of the judges recently seconded even became presidents of the higher instance courts. According to Article 77 of the Law on common courts system, since 3 April 2018 it is even possible for a judge of the district court to be seconded to the Supreme Court (so far, district court judges could have been only assistants of the Supreme Court Judges). ${ }^{22}$ The decision shall be made by the MoJ at the request of the First President of the SC or President of a Disciplinary Chamber of the SC and the only requirement will be 10 years of professional experience. The secondment of judges to higher tiers of courts (in reasonable proportions and if justified by the situation and needs as well as the professional qualifications of the judge) as such could be seen as justified according to the European standards, yet the idea of appointment of lower tier court judges as higher courts presidents seems to contradict the standards from the CCJE Opinion No. 19 (2016): 'The minimum qualification to become president of a court is that the candidate should have all the necessary qualifications and experience for appointment to judicial office in that court'.

Another issue which should be noticed is the number of the seconded judges in a certain court, especially with regard to the Supreme Court (there should be a reasonable proportion between the number of judges of a given court and the number of seconded judges); the law says nothing in this regard.

\subsubsection{Appointment and Dismissal of Court Presidents}

According to a transitional provision of the Act of 12 July (Article 17), within the 6-month period after the adoption of the Act (that is until 12 February 2018), the MoJ was able to dismiss and appoint courts' presidents at their discretion (and, according to media report, the Minister has used his power in this period by removing 149 court presidents and vice-presidents, including 10 out of 11 presidents of courts of appeal).

After this transitional period the MoJ, according to the Act, retains the power to appoint and dismiss court presidents and vice-presidents but the MoJ decision on dismissal of court presidents/vice-presidents must be consulted with the National Council of the Judiciary. The MoJ decision can be overturned only by a qualified, 2/3 majority of Council's members (so far, the ordinary majority was sufficient in this regard). Appointment of the presidents of any ordinary court is made by the MoJ alone, no substantive conditions required to this decision.

The requirements for the court president/vice-president's function have also been lowered. Before August 2017, a judge of a lower tier court could not become a court president. The amendments to the law on common courts system provide that in the court of appeal, it will also be possible to appoint: regional court judge as a vice-resident/ president of the court of appeal, as well as a district court judge as a president/vicepresident of the regional court. Both decisions shall be now made by the MoJ without

22 In fact, now it will be possible for a district court judge to become a Supreme Court judge, as requirement of 10 years ' experience spent in judiciary (regardless of the position in the structure of judiciary) is sufficient. 
prior consultation with National Council of the Judiciary, ${ }^{23}$ general assembly of judges of the area of jurisdiction or court college. The powers of MoJ vis-à-vis court presidents seem to broadly exceed the desired scope of competencies stemming from European standards. For instance, according to the Venice Commission recommendations from its Opinion of 2017: 'The decision of the Minister of Justice to appoint/dismiss a court president should be subject to approval by the National Council of the Judiciary or by the general assembly of judges of the respective court, taken by a simple majority of votes. Ideally, general assemblies of judges should submit candidates to positions of presidents to the Minister of Justice for approval. The Minister of Justice should not have 'disciplinary' powers vis-à-vis court presidents; any sanction on court presidents should be imposed according to the same procedure as a disciplinary sanction against a judge. ${ }^{24}$ The discretionary powers of the Minister of Justice with regard to the appointment and (in certain extent) dismissal of the court presidents seem not to be in line with CCJE Opinion No. 19(2016): ${ }^{25}$ 'The CCJE also wishes to stress that, irrespective of the existing rules of procedures and what bodies are empowered to decide which candidate will take on the position of court president, what is essential is that the best candidate is selected and/or appointed as stated in Recommendation CM/ $\operatorname{Rec}(2010) 12$ and in CCJE Opinion No.1(2001): the authorities responsible in member States for making and advising on appointments and promotions should now introduce, publish and give effect to objective criteria, with the aim of ensuring that the selection and career of judges are based on merit, having regard to qualifications, integrity, ability and efficiency. The CCJE is of the opinion that the judges of the court in question could be involved in the process. This can take the form of a binding or advisory vote. In some member states, presidents of courts are not selected and/or appointed but are elected by their peers - the judges of the court. The CCJE is of the opinion that in such a system, objective criteria of merit and competence should also prevail (...) The safeguards of irremovability from office as a judge apply equally to the office of a court president'. According to the Venice Commission 'promotion' implies inter alia appointment as a court president; the Venice Commission expressed a clear preference for a system where court presidents are elected by the judges of the respective court. ${ }^{26}$

\subsection{SUPREME COURT}

A new law on the Supreme Court was passed by Parliament at the end of 2017. Compared to the provisions in the current Law on the Supreme Court, the new act (which entered into force at the beginning of April 2018) introduces new solutions in the following areas:

1) New corrective institution of final judicial decisions called the extraordinary complaint;

2) Changes in the structure of the Supreme Court;

$23 \quad$ Positive opinion of the Council was obligatory for appointment of a court president.

24 Venice Commission, 'Opinion No 904 / 2017', 11 November 2017.

25 CCJE, 'Opinion No 19 on the role of court presidents', 8-10 November 2016.

26 Venice Commission and Directorate of Human Rights (DHR) of the Directorate of Human Rights and the Rule of Law (DGI) of the Council of Europe, 'Joint Opinion on the draft Law on Amendments to the Organic Law on General Courts of Georgia' CDL-AD(2014)031 \$ 84; See also Venice Commission, 'Opinion No 855 / 2016' CDL-AD(2017)018, 9 October 2017, $\$ 81$. 
3) The participation of lay judges, as a social factor in certain proceedings before the Supreme Court (i.e. extraordinary complaints and disciplinary proceedings).

The new law on the Supreme Court was prepared without the proper consultation with the judiciary. As noted in the August 2017 Opinion, the CCJE has recommended that 'the judiciary should be consulted and play an active part in the preparation of any legislation concerning their status and the functioning of the judicial system'. According to the opinion of judges of the Supreme Court, stated in the Supreme Court Resolution of 16 January 2018, new law on the Supreme Court has been prepared in violation of fundamental rules of law-making, without adequate consultation, with disrespect to revealed scientific opinions and positions of legal and academic organizations. Executive Board of European Network of Councils for the Judiciary (ENCJ) stressed that throughout the process that has led to the amendments, there has been no meaningful consultation with the National Council of Judiciary (KRS) or the judges themselves. According to ENCJ standards, the Judiciary should always be involved at all stages of any reform process, whether directly or through appropriate consultation. This is to ensure the independence of the judiciary. Judges and judicial councils should not be hostile to modernization and reform, provided always that the contemplated reforms are aimed at improving the quality of the justice system for the benefit of those that it serves. It is for this reason that judicial involvement in the reform process is essential: it provides the balance between the wishes of the elected government and the need to maintain judicial impartiality and the Rule of Law.

\subsubsection{Extraordinary Complaint (Article 86)}

According to the new law it is possible to bring an extraordinary action before the Supreme Court from any final court ruling, if:

1) The decision violates the rules or the freedoms and rights of human and of the citizen specified in the Constitution,

2) Judgment significantly violates the law by its erroneous interpretation or misapplication,

3) There is an obvious contradiction of significant findings by the Court with the content of the collected evidence, and a judgment cannot be repealed or amended by other extraordinary remedies.

The extraordinary complaint, according to the first version of the adopted law, might have been brought only by specific bodies, i.e. the Prosecutor General, Ombudsman, a group of at least 30 MPs or 20 senators, and, within their scope of activities - the President of the General Counsel to the Republic of Poland, the Ombudsman for Children, the Ombudsman for Patients' Rights, Chairman of the Financial Supervision Commission and the Financial Ombudsman. Finally, only the Prosecutor General and Ombudsman are entitled to bring the extraordinary complaint to the Supreme Court. The extraordinary complaint shall be filed within five years from when the contested decision became valid or, if there was a cassation procedure, within a year from when the cassation was heard. It is unacceptable to take account of the emergency action to the detriment of the accused lodged after 6 months from when either the decision became valid or the cassation was heard. Extraordinary complaints cannot be based on the same grounds, which had been the subject of cassation procedure. If Supreme Court takes the complaint into account, it 
shall repeal the contested decision and, in accordance with the results of the hearing, shall decide on the merits of the case or shall refer the matter back to the competent court, if necessary, repealing also the judgment of the Court of first instance, or shall discontinue the proceedings. The Supreme Court shall dismiss an extraordinary complaint, if it finds no grounds for the setting aside of the judgment under appeal.

The extraordinary complaint shall be recognised by the Supreme Court panel composed of two judges of the Supreme Court sitting in the newly established Chamber of Extraordinary Control and Public Affairs and one lay judge of the Supreme Court, appointed by the First President (see below). If the complaint concerns an extraordinary decision of the Supreme Court, the case shall be recognised by the Supreme Court panel composed of five judges of the Supreme Court sitting in the Chamber of Extraordinary Control and Public Affairs and two lay judges of the Supreme Court.

What is important, during the period of three years from the date of entry into force of the Act (i.e. 2 April 2018), extraordinary complaint can be brought with respect to judgments ending the proceedings in matters which became final after 17 October 1997 which means that until April 2021 all judgments issued within the last 20 years may be repealed, by means of this new legal instrument.

As noted by the Consultative Council of European Judges (CCJE), 'the enforcement of a decision must not be undermined by extraneous intervention whether from the executive or the legislator by imposing retroactive legislation'. Indeed, 'the very notion of an "independent" tribunal set out in Article 6 of the ECHR implies that its power to give a binding decision may not be subject to approval or ratification, or that the decision may not be altered in its content, by a non-judicial authority, including the Head of State. It has been noticed that the introduction of new appeals procedure, combined with the possibility to reopen numerous final judgments, also has to be considered in the broader context of an already overloaded judicial system, as demonstrated by the abundant recent case-law of the ECtHR concerning Poland on the excessive length of judicial proceedings. In that respect, structural features in a legal system that cause delays in judicial proceedings are not an excuse under Article 6 of the ECHR or Article 14 of the ICCPR, as well as Art. 47 of the European Charter of Fundamental Rights. In light of the foregoing, the introduction of this extraordinary review of final court decisions raises serious prospects of incompatibility with key rule of law principles, including the principle of res judicata and the right to access justice. It also runs the risk of potentially overburdening the Supreme Court. The same goals of protecting the rule of law and social justice could be achieved through the proper use of already available general or cassation appeals to ensure the rectification of judicial errors or other deficiencies before judgments become final and enforceable.

\subsubsection{Changes in the Structure of the Supreme Court}

According to the new law it is the President of the Republic of Poland and not the General Assembly of the judges of the Supreme Court (as it has been so far) who issues the Rules of the Supreme Court that specify, among others, the number of judicial posts in the Supreme Court, including the number of posts in the particular chambers, the internal organisation of the Supreme Court, the rules of internal procedure and a detailed scope of jurisdiction and competences of judicial assistants. 
The law provides for creation of two new Chambers of the Supreme Court - Chamber of Extraordinary Control and Public Affairs and the Disciplinary Chamber.

The Chamber of Control and Public Affairs shall hear extraordinary complaints. It shall also take over the cases from the public law area, previously dealt with by the Chamber of Labour, Social Insurance and Public Affairs (including resolution of electoral protests, protests against the validity of the a nationwide referendum and the constitutional referendum and to uphold the validity of the elections and referenda), as well as complaints about excessive length of proceedings before the ordinary and military courts.

Interestingly enough, the Disciplinary Chamber enjoys a special status among the Chambers of the Supreme Court. Part of the competences of The First President of the Supreme Court and the General Assembly of the judges of the Supreme Court shall be performed by the Head of the Disciplinary Chamber and the Assembly of the judges of the Disciplinary Chamber. The disciplinary chamber will be able to independently shape its budget, although the planned spending amount cannot be higher than $15 \%$ of the average expenditure of the Supreme Court.

The following matters are included in its scope of jurisdiction: 1) disciplinary cases concerning the judges of the Supreme Court; 2) disciplinary cases in which (on the basis of separate provisions) Supreme Court is competent (i.e. disciplinary matters relating to: prosecutors, advocates, solicitors, notaries, bailiffs, doctors and other professionals); 3) complaints concerning the excessive length of the proceedings in the Supreme Court.

The Military Chamber has been abolished, its 6 judges retired, and its material jurisdiction transferred to the Criminal Chamber.

As stated by the Venice Commission, ${ }^{27}$ the power given to the President to issue the Rules of Procedure of the Supreme Court, especially with respect to the first Rules of Procedure, where this is done without requiring the opinion of the Supreme Court Board, is incompatible with the principles of judicial independence and of the separation of powers. It is recommended to retain the power to determine the regulations of the Supreme Court in the General Assembly of the Supreme Court or in some other independent judicial body such as the Board of the Supreme Court. Enhanced control of the President of the Republic of Poland over the work of the Chambers, and thus the Supreme Court as a whole, is unjustified and risks violating the principle of the independence of the judiciary.

\subsubsection{Lay Judges}

It must be noted that in Poland the participation of lay judges in court proceedings has been diminished. What is more, lay judges never composed the benches in the Supreme Court, as it is a court of law, not the court of facts. According to the new law, lay judges will participate in panels which shall decide in disciplinary proceedings conducted before the Supreme Court and in cases of extraordinary complaints. Supreme Court lay judges would be selected by the Senate of the Republic for a 4 year term out of candidates reported by citizens, directly or through community organizations. The number of lay judges in the Supreme Court of State would be established by College of the Supreme Court.

27 European Commission for Democracy through Law, 'Opinion No. 904 / 2017', Strasbourg, 11 December 2017, CDL-AD(2017)031. 
The Venice Commission reiterated that the Polish Constitution does not specify the forms of participation of members of the public in the administration of justice (see Article 182 of the Constitution), leaving this question to regulation by statute. In principle, mixed benches including professional judges and lay members/jurors exist in a number of modern European jurisdictions, but they are usually present in lower instances. In the jury trial the sole responsibility of jurors is to answer questions of fact. Lay members are usually absent from the high courts and this is for an obvious reason: such courts are called to examine complex questions of law.

In the opinion of the Venice Commission, the proposal to introduce lay members, in particular in the two special chambers of the SC, is dangerous for the efficiency and for the quality of justice. Venice Commission concluded that the proposal has evident similarities to the Soviet judicial system. ${ }^{28}$

The main change in the functioning of the Supreme Court, however, was aimed at lowering the retirement age, thus leading to getting rid of a profound number of the Supreme Court judges (similar regulations, i.e. lowering the retirement age, were introduced with regard to female judges in the ordinary courts). The adoption by Parliament of two Acts (on the Supreme Court and on the National Council of Judiciary) at the beginning of July 2017, provoked massive protests and demonstrations in Poland, including not only the Polish judiciary but the public at large, and was also strongly criticized by the CoE, the EU and range of international, i.e. ENCJ, CCBE, EAJ, AEAJ, and national Councils for the Judiciary in EU Member States. In particular, the CoE Secretary General sent a letter, of 18 July 2017, to the Speaker of the Polish parliament concerning the draft Act on the Supreme Court.

Nevertheless, it was the Court of Justice decision on interim measures, which made the Polish authorities to give up the idea of lowering the retirement of judges.

\subsection{NATIONAL COUNCIL FOR JUDICIARY}

The act amending the law on the National Council of Judiciary introduces new solutions in the following areas:

1. Entrusting the Sejm (lower chamber of Parliament) with the competence to elect the members of the Council;

2. Termination of office of the current members of the Council.

\subsubsection{Entrusting the Sejm with the competence to elect the members of the Council}

The amended law envisages that the 15 judges - members of the Judicial Council will be elected by Sejm by 3/5 majority, yet if Sejm fails to do so, ordinary majority applies. According to most scholars in Poland, entrusting Sejm with the competence to elect the judicial members of the Council deprives the members of the Council the feature of being the representatives of judicial self-government, is not in line with Article 10(1), Article 173 and Article 187(1)(2) of the Constitution and leads to the politicization of courts.

28 European Commission for Democracy through Law, 'Opinion No. 904 / 2017' CDL-AD(2017)031, Strasbourg, 11 December 2017. 
The constitutional issue is not in the majority of votes required to grant a mandate to a member of the Council, but in the very intention of entrusting the Sejm with the competence to do so.

The ENCJ standards ${ }^{29}$ in this field stipulate that: '..... the mechanism for appointing judicial members of a Council must be a system which excludes any executive or legislative interference and the election of judges should be solely by their peers and be on the basis of a wide representation of the relevant sectors of the judiciary.' Another ENCJ standard is that at least $50 \%$ of the members of the Council should be judges, elected by their peers. It is obvious that the election of the judicial members of the Council by Parliament, whether by simple or qualified majority, is not in accordance with the ENCJ standards. Given that 15 judicial members are not elected by their peers, but receive their mandates from Parliament, six other members of the Council are parliamentarians, and four others are ex officio members including a person appointed by the President of the Republic (see Article $187 \S 1$ of the Constitution), the new law leads to a Council dominated by political nominees. The CCJE Bureau in its Opinion adopted on 7 April 2017 emphasised that it was concerned that the Act would be a major step backward from real judicial independence in Poland. The Bureau of the CCJE was deeply concerned, in particular, by the implications of the Act for the constitutional principle of separation of powers as well as that of the independence of the judiciary, as it effectively meant transferring the power to appoint members of the National Council of the Judiciary from the judiciary to the legislature. In order to fulfil the European standards on judicial independence, the judgesmembers of the Council should continue to be chosen by the judiciary. The Bureau also underlined that the pre-term removal of the judges currently sitting as members of the Council would not be in accordance with European standards on judicial independence.

\subsubsection{Termination of Office of the Current Members of the Council}

According to Articles 6 and 7 of the above-mentioned act, amending the Law on the National Council of Judiciary, the terms of office of current members of the Council who were elected from among judges of the Supreme Court, administrative courts, common courts and military courts for a constitutionally guaranteed 4-year term of office be terminated (which is clearly not in line with Article 187(3) of the Constitution). Moreover the term of office of the current members of the Council selected by the Parliament is not terminated, which means that the lawmaker does not treat the elected members of the Council in the same manner.

As Executive Board of European Network of Councils for the Judiciary (ENCJ) reiterated in its opinion: the amendments to the law on the National Council of Judiciary should not be seen as an isolated issue, but rather in conjunction with the amendments to the Act on the Ordinary Courts and the Act on the Supreme Court. Taken together, the recent amendments to the laws governing the judiciary seem like the legislature is trying to control the third power of the State, the judiciary. This is alarming and will potentially affect the position of and trust in the Polish judiciary in the European legal community. The Rule of Law is at the core of the European Union and is central to any democratic system. Respect for the Rule of Law is a prerequisite for the protection of all fundamental

European Network of Councils for the Judiciary, Executive Board Opinion, Brussels, 5 December 2017. 
values listed in the Treaties, including democracy and fundamental rights. To uphold and protect the Rule of Law is a responsibility for both the Judiciary and the other State powers. For the effective preservation of the Rule of Law, independent and accountable justice systems are needed with fair and impartial courts as the key institutions. The fair and impartial courts are the key institutions of an independent judiciary. A key requirement for maintaining and enhancing mutual trust between judicial authorities in the EU, as a basis for mutual recognition of judicial decisions, is the independence, quality and efficiency of the judicial systems and respect for the Rule of Law.

\section{JUDICIAL REFORM IN UKRAINE IN 2016: PROBLEMS OF IMPLEMENTATION}

\subsection{GENERAL CHARACTERISTICS OF THE JUDICIARY IN UKRAINE}

According to part 1 , Article 6 of the Constitution of Ukraine, ${ }^{30}$ state power in Ukraine is exercised on the principles of its division into legislative, executive and judicial power. Chapter VIII of the Constitution of Ukraine 'Justice' is dedicated to the backgrounds of organization and activity of the judicial branch of power in Ukraine. Ukrainian researchers criticize the title of this section, claiming that it is better to change the name to 'Judiciary', which is used in most constitutions of the world. ${ }^{31}$ Indeed, this title logically follows the structure and content of Article 6 of the Constitution of Ukraine. It is obvious, however, that in choosing the name of the said part, the Main Law creator's desire of administering real justice in Ukraine prevailed, which means exercising truly legal decisions regarding conflicts at hand. The judiciary has an important role and functions in relation to the other two pillars of power. It ensures that governments and the administration can be held to account for their actions, and, with regard to the legislature, it is involved in ensuring that duly enacted laws are enforced, and, to a greater or lesser extent, that they comply with any relevant constitution or higher law (such as that of the European Union). To fulfill its role in these respects, the judiciary must be independent of these bodies, which involves freedom from inappropriate connections with and influence by these bodies. ${ }^{32}$

Today, Ukraine is on the way of building a judicial system capable of making judiciary decisions independently. And this study is devoted to the analysis of recent steps taken in the course of modern judicial reform, which began with the introduction of amendments to the Constitution of Ukraine on 2 June 2016.

Since our research is carried out in a constitutional and legal aspects, it will be logical to begin with an analysis of the essence of judicial reform in terms of reorganization of the status of constitutional justice in Ukraine.

$30 \quad$ Konstytutsiia Ukraiiny [Constitution of Ukraine]: pryiniata na piatii ses. Verkhovn. Rady Ukraiiny 28.06.1996, Vidomosti Verkhovnoii Rady Ukraiiny (1996) № 30, St. 141 < http://zakon2.rada.gov.ua/ laws/show/254к/96-вр> accessed 5 May 2019.

31 See, for example, M Savenko, The legal status of the Constitutional Court of Ukraine (author's abstract of dissertation for the degree of candidate of legal sciences: specialty 12.00.02, Kharkiv 2005) 20, at 5.

32 Reccomendation Rec (94)12. 


\subsection{STATUS OF THE CONSTITUTIONAL COURT OF UKRAINE. MAIN INNOVATIONS}

\subsubsection{Statutory Aspect of the Independence of the Constitutional Court of Ukraine}

The status of the Constitutional Court of Ukraine is regulated in detail by a separate, XII Chapter of the Constitution of Ukraine named 'The Constitutional Court of Ukraine'. Such an approach to constitutional regulation of bodies of constitutional jurisdiction reflects, in general, the tendency that takes place in foreign countries. Thus, for instance, the Constitutions of France, Italy, Spain ${ }^{33}$ also contain separate chapters on specialized bodies of constitutional control. It is constitution that determines the competence of a body of judicial constitutional control, the order of their forming, the procedure of appeal to them, and the consequences of recognition of a law as such, which doesn't conform to the constitution. Laws on constitutional courts adopted in development of constitutional statements are, as a rule, organic (constitutional). However, the legislative system of Ukraine doesn't include such category of laws as constitutional or organic. All of the laws in Ukraine are normal (ordinary). The latter as well includes the Law of Ukraine 'On Constitutional Court of Ukraine' of 13 June 2017, adopted to replace the Law of Ukraine 'On Constitutional Court of Ukraine' of 16 October 1996.Thus, according to the abovementioned Law of Ukraine 'On the Constitutional Court of Ukraine', the organization of the internal activities of the Court and the respective rules of procedure shall be established by the Rules of Procedure of the Constitutional Court of Ukraine (hereinafter - the Rules of Procedure) (Article 3 of the Law). The Court shall adopt the Rules of Procedure and their amendments during a special plenary session. The Rules of Procedure and their amendments are considered to be adopted if at least two quarters of the constitutional composition of the Court voted it their favour (Article 96 of the Law).

Arguments of the supporters of subordinate regulation of procedure of activities of the Constitutional Court of Ukraine mostly come to the fact that the rules of procedure of a body are an internal document which regulates the procedure of its activity and thus, it shall be adopted by the body itself. Moreover, the existence of veto right of the President of Ukraine upon the laws can be considered as a form of intervention in the internal procedure of activity of the Constitutional Court of Ukraine which shall operate independently from any influence. Also, the subjects with the right of legislative initiative can as well apply it to the statements of the code of procedure of the Constitutional Court of Ukraine in case of its approval by law.

Such position finds recognition in the documents of the European Commission 'For Democracy through Law' (Venice Commission). Thus, according to Opinion on the Rules of Procedure of the Constitutional Court of Azerbaijan (CDL-AD (2004)023) ${ }^{34}$ (paragraphs 5,6 ), the legal basis of the activity of each constitutional court is usually formed by three kinds of legal regulations having different positions in the hierarchy of

33 Thus, Chapter IX of the Constitution of Spain of 1978 is named 'On the Constitutional Court', Chapter IV of the Constitution of Italy of 1947 is named 'The Constitutional Cour', Chapter VII of the Constitution of France of 1958 is named 'Constitutional Council'.

Venice Commission, 'Opinion on the rules of procedure of the Constitutional Court of Azerbaijan' CDL-AD(2004)023, Strasbourg, 23 June $2004<$ http://www.venice.coe.int/webforms/documents/ default.aspx?pdffile $=$ cdl-ad $(2004) 023-e>$ accessed 5 May 2019. 
norms of the domestic legal order of the state. They play different roles in the process of the complete and coherent legal regulation of the constitutional body. On the 'top' of this triad is usually the constitution establishing the jurisdiction of the court, the parties entitled to appeal as well as the constitutional principles on which the activity of the constitutional court is to be based. Laws on constitutional courts usually transform these constitutional principles into more concrete norms. Finally, the rules of procedure constitute the next and last level of this triad. They fill in practical details of the everyday judicial activity. The Rules of Procedure should be drafted by the constitutional court itself. Speaking about the way of approval of the rules of procedure of the Constitutional Court, the other document of Venice Commission (Opinion of European Commission 'For Democracy through Law' on the Rules of Procedure of the Constitutional Chamber of the Supreme Court of the Kyrgyz Republic CDL-AD (2015)023), ${ }^{35}$ states that these rules should ideally be drafted by the court itself, which should enjoy a certain amount of autonomy within the limits of the constitution and the law that give the court the possibility of modifying the rules without the intervention of the legislator.

As a counter plea to the stated position we should mention that, firstly, the procedures of activities, specified in the Rules of Procedure of the Constitutional Court of Ukraine, cannot be solely internal because, as we know, there are other parties (physical and legal persons) in the constitutional procedure apart from the Court itself. This counter plea is especially important in the light of the introduction in Ukraine of the institute of constitutional complaint (which will be discussed later). Secondly, the exercising by the head of the state of veto right is possible on condition of non-conformity with a law of the Constitution of Ukraine. Moreover, such a law can be an object of constitutional control from the part of the Constitutional Court in future.

As we know, bodies of constitutional control, passing their resolutions or creating court precedents, can take an active part in the political life of the state and contribute to the implementation of the political course of the state. In doing so, they must depart from the principle of so-called political restraint, or political impartiality, the idea of which lies in the refusal of the abovementioned bodies to interfere in political issues and situations: their activity is limited to the consideration of exclusively legal issues. ${ }^{36}$ Briefly characterizing the standards of the principle of impartiality in court activity in general, we should mention that, according to paragraph 2 Magna Carta of Judges, judicial independence and impartiality are essential prerequisites for the operation of justice. ${ }^{37}$ The idea of the principle of impartiality is characterized as follows: when adjudicating between any parties, judges must be impartial, that is free from any connection, inclination or bias, which affects - or may be seen as affecting their ability to adjudicate independently. In this regard, judicial independence is an elaboration of the fundamental principle that 'no man may be a judge in his own cause. This principle also has significance well beyond that affecting the particular

35 Opinion on the Rules of Procedure of the Constitutional Chamber of the Supreme Court of the Kyrgyz Republic CDL-AD(2015)023 <http://www.venice.coe.int/webforms/documents/?pdf=CDL$\mathrm{AD}(2015) 023-\mathrm{e}>$ accessed 5 May 2019.

36 V Tumanov, 'Constitutional backgrounds of the judiciary' in MV Bahlai, YuI Leibo, LM Entin (eds), Constitutional law of foreign countries: textbook for high school (Norma 2005) 409.

37 Magna Carta of Judges (Fundamental Principles), Consultative council of European judges (CCJE), 17 November 2010, Strasbourg <http://www.vru.gov.ua/content/file/Opinion_1-18.pdf > accessed 5 May 2019. 
parties to any dispute. Not merely the parties to any particular dispute, but society as a whole must be able to trust the judiciary. A judge must thus not merely be free, in fact, from any inappropriate connection, bias or influence, he or she must also appear to a reasonable observer to be free therefrom (paragraph 12 of Opinion No. 1 (2001) of the Consultative Council of European Judges for the attention of the Committee of Ministers of the Council of Europe on standards concerning the independence of the judiciary and the irremovability of judges)..$^{38}$ According to paragraph 20 of the Opinion No. 3 (2002) of the Consultative Council of European Judges to the attention of the Committee of Ministers of the Council of Europe on the principles and rules governing judges' professional conduct, in particular ethics, incompatible behaviour and impartiality, impartiality is determined by the European Court both according to a subjective approach, which takes into account the personal conviction or interest of a particular judge in a given case, and according to an objective test, ascertaining whether the judge offered guarantees sufficient to exclude any legitimate doubt in this respect. ${ }^{39}$ Paragraph 33 of the abovementioned Opinion indicates the need to strike a balance between the judges' freedom of opinion and expression and the requirement of neutrality. It is, therefore, necessary for judges, even though their membership of a political party or their participation in public debate on the major problems of society cannot be proscribed, to refrain at least from any political activity liable to compromise their independence or jeopardise the appearance of impartiality. Analyzing the content of the Ukrainian legislation in this part, it is worth noting that, according to Article 148 of the Ukrainian Constitution, the judges of the Constitutional Court of Ukraine shall not belong to political parties, trade unions, take part in any political activity, hold a representative mandate, occupy any other paid office, or perform other remunerated work, except scholarly, teaching or creative activities.

However, judges in western European countries usually restrain themselves only from active participation in political party and trade union activity (not from being a member of a political party or trade union in general).

In Ukraine the question of political impartiality of judges of the Constitutional Court of Ukraine is especially sharp. Thus, the most problematic aspect of the implementation of this principle is the adoption of an unprecedented in the practice of world constitutionalism Decision of the Constitutional Court of Ukraine of 30 September 2010 ${ }^{40}$ which proclaimed the Law of Ukraine 'On Amendments to the Constitution Ukraine' of 8 December 2004, No. 2222-IV to be incompatible with the Constitution of Ukraine (unconstitutional). In its activity the Constitutional Court of Ukraine also applies the principle of 'related initiative', according to which a court cannot examine

38 CCJE, 'Opinion No 1 on standards concerning the independence of the judiciary and the irremovability of judges' <http://www.vru.gov.ua/content/file/Opinion_1-18.pdf> accessed 5 May 2019.

39 CCJE, 'Opinion No 3 on the principles and rules governing judges' professional conduct, in particular ethics, incompatible behaviour and impartiality’ <http://www.vru.gov.ua/content/file/Opinion_1-18. pdf $>$ accessed 5 May 2019.

40 The decision of the Constitutional Court of Ukraine in the case of the constitutional petition of 252 People's Deputies of Ukraine regarding the compliance with the Constitution of Ukraine (constitutionality) of the Law of Ukraine 'On Amendments to the Constitution of Ukraine' of 8 December 2004 № 2222-IV (the case of adhering to the procedure for amending the Constitution of Ukraine) of 30 September 2010 No 20-pп/2010<http://zakon.rada.gov.ua/laws/show/v020p710-10> accessed 5 May 2019. 
the question of constitutionality of normative acts, including laws, by its own initiative. ${ }^{41}$ This principle is also a constituent part of the principle of judicial impartiality.

\subsubsection{Functional Aspect of the Independence of the Constitutional Court of Ukraine.}

This aspect of the independence means that it is the only body of constitutional jurisdiction with such procedure of formation and powers that allow it to maintain balance in the relations between the branches of power.

As it goes in the document of European Commission 'For Democracy through Law' (Venice Commission) 'The Composition of Constitutional Courts', December 1997, CDL-STD (1997)020 ${ }^{42}$ notwithstanding the complexity of the various systems of the composition of constitutional courts, three main fields of legislative concern could be identified. These are balance, independence and effectiveness. Society is necessarily pluralist - a field for the expression of various trends, be they philosophical, ethical, social, political, religious or legal. Constitutional justice must, by its composition, guarantee independence with regard to different interest groups and contribute towards the establishment of a body of jurisprudence which is mindful of this pluralism. The legitimacy of a constitutional jurisdiction and society's acceptance of its decisions may depend very heavily on the extent of the court's consideration of the different social values at stake, even though such values are generally superseded in favour of common values. To this end, a balance which ensures respect for different sensibilities must be entrenched in the rules of composition of these jurisdictions. Given the diversity of constitutional justice systems, it is difficult to identify a set of minimum guarantees of independence to be provided in the composition of constitutional courts. Broadly, the following points may provide some guidance, though specific circumstances in a State may well justify a variation of these measures.

Let us compare the statements from the abovementioned recommendations of Venice Commission concerning the guarantees of constitutional courts independence with the guarantees secured in the legislation of Ukraine and determine respective problematic aspects.

1) Thus, according to the abovementioned recommendations of Venice Commission CDL-STD(1997)020, a ruling party should not be in a position to have all judges appointed to its liking. Hence, terms of office of constitutional judges should not coincide with parliamentary terms. One way of accomplishing this can be by long terms of office or office until the age of retirement. In the former case, reappointment would be possible either only once or indeed not at all (paragraph 10).

Parliamentary term in Ukraine is 5 years, whereas the term of office of a judge of the Constitutional Court of Ukraine is 9 years. The President of Ukraine, the Verkhovna Rada of Ukraine and the Congress of Judges of Ukraine each appoint six judges to the Constitutional Court of Ukraine. Thereby, not all subjects who appoint judges to the Constitutional Court of Ukraine are related to the parliamentary majority (ruling party). At the same time, according to Ukrainian experts, the model of the formation of

41 Tumanov (n 46).

42 Venice Commission, 'The Composition of Constitutional Courts' CDL-STD(1997)020 (December 1997) <http://www.venice.coe.int/webforms/documents/?pdf=CDL-STD(1997)020-rus> accessed 5 May 2019. 
the Constitutional Court of Ukraine secured in the current legislation in Ukraine is not optimal, in connection with which the literature proposes to introduce such a formation of the Constitutional Court in Ukraine, which would be carried out on a competitive basis on the principle of rotation of a third of judges every three years from among the scholars and practitioners from various fields of law with the possible advantage of experts in the field of constitutional law. ${ }^{43}$ 2) According to Venice Commission, the rules of incompatibility should be rather strict in order to withdraw a judge from any influence which might be exerted via his/her out-of-court activities (paragraph 5 of the document CDL-STD(1997)020).

This aspect has already been analyzed above in the research of the question of political neutrality of judges of the Constitutional Court of Ukraine.

3) As stated by Venice Commission, disciplinary rules for judges and rules for their dismissal should involve a binding vote by the court itself. Any rules for dismissal of judges and the president of the court should be very restrictive. Furthermore, special provision might be necessary in order to maintain the effective functioning of the court when vacancies arise (paragraph 6 of the document CDL-STD (1997)020).

In connection with the position of Venice Commission from the previous paragraph regarding the formation of constitutional courts, let us note the following changes in the formation of the Constitutional Court of Ukraine, which took place after the adoption of amendments to the Constitution of Ukraine of 02 June 2016.

The first novelty if that election of candidates for the post of judge of the Constitutional Court of Ukraine shall be conducted on competitive basis under the procedure prescribed by the law (part 3, Article 148 of the Constitution of Ukraine). Such a competition is currently in progress in Ukraine, so it will be possible to evaluate its results only afterwards.

Secondly, an important novelty in the aspect of guaranteeing independence of judges of the Constitutional Court of Ukraine is determining the grounds for termination of a judge's tenure without necessity to approve a special decision. According to the Constitution of Ukraine, such grounds include: 1) expiry of the term of judge 's office; 2) his or her attainment of the age of seventy ${ }^{44}$; 3 ) termination of Ukraine's citizenship or acquiring by him or her the citizenship of another state; 4) taking effect of a court's decision on recognition or declaration of a judge of the Court missing or dead, or on recognition of a judge of the Court to be legally incapable or partially legally incapable; 5) taking effect of a guilty verdict against him or her for committing a crime; 6) death of a judge of the Constitutional Court of Ukraine. At the same time, after the amendments of 2016 to the Constitution of Ukraine, the grounds for dismissal of a judge of the Constitutional Court of Ukraine have been defined, which include the following: 1) inability to exercise his or her powers for health reasons; 2) violation by him or her of incompatibility requirements; 3) commission by him or her of a serious disciplinary offence, flagrant or permanent disregard of his or her duties incompatible with the status of judge of the Court or revealing

43 Savenko (n 41).

44 Prior to the abovementioned changes, the powers of the judges of the Constitutional Court of Ukraine by age ceased on a general basis with judges of courts of general jurisdiction, that is, upon reaching the age of 65 . 
non-conformity with being in the office; 4) submission by a judge of statement of resignation or of voluntary dismissal from office. In these cases, dismissal of a judge of the Constitutional Court of Ukraine from his or her office shall be decided by not less than two-third votes of full Court.

It is important that during the judicial reform the previously existing principle of termination of powers of the judge of the Constitutional Court of Ukraine, in which the decision on dismissal was accepted by the subject that appointed him, was changed. Thus, the judge of the Constitutional Court of Ukraine when making appropriate decisions was forced to constantly 'consult' with the opinion of the subject which appointed him or her under the threat of possible dismissal from office.

4) Venice Commission also states that rules on appointment should foresee the possibility of inaction by the nominating authority and provide for an extension of the term of office of a judge until the appointment of his/her successor. In case of prolonged inaction by this authority, the quorum required to take decisions could be lowered (paragraph 4.3. of the document CDL-STD (1997)020).

The effective Law of Ukraine 'On the Constitutional Court of Ukraine' specifies the term during which the subjects of appointment of judges of the Constitutional Court of Ukraine shall appoint a judge in case of occurrence of a vacant office (3 months). However, this Law doesn't provide for the mechanisms solving of constitutional conflicts in case of prolonged inactivity of persons responsible for appointment of judges of the Constitutional Court of Ukraine. This gap of legal regulation needs settlement.

5) According to Venice Commission, the effectiveness of a constitutional court also requires there to be a sufficient number of judges, that the procedure would not be overly complex and that the court has the right to reject individual complaints which do not raise a serious issue of constitutional law. All of these points remain necessarily vague and will have to be adapted to each specific case. Taken together, they can, however, provide an idea of some issues to be tackled in order to create a balanced, independent and effective court (paragraph 10 of the document CDL-STD (1997)020).

Commenting on the changes in the functional component of the status of the Constitutional Court of Ukraine, first of all, the emergence in Ukraine of a new instrument for the protection of the constitutional rights and freedoms of a person and a citizen entitled 'constitutional complaint' should be noted.

The subject of the right to constitutional complaint in Ukraine is a person alleging that the law of Ukraine (or particular parts of it) applied in a final decision in his or her case contravenes the Constitution of Ukraine.

The entities of the right to a constitutional complaint do not include legal persons of public law. In particular, this means that a constitutional complaint is not open to local self-government. The constitutional amendments on local self- government have not yet been adopted and this question should be settled in a separate procedure within that framework. ${ }^{45}$. A constitutional complaint is considered to be admissible if it complies with the formal requirements stipulated by the Law of Ukraine 'On the Constitutional

45 See Venice Commission, 'Opinion on the Draft Law on the Constitutional Court of Ukraine' (9-10.12.2016 № 870/2016) <http://www.scourt.gov.ua/clients/vsu/vsu.nsf> accessed 5 May 2019. 
1) all national judicial remedies have been exhausted (in the presence of a court decision approved in the order of appeal, which has come into force, and in the case of the possibility of a cassation appeal provided for by law - a court decision made in the cassation review procedure);

2) no more than three months have expired from the date of entry into force of the final court decision, in which the law of Ukraine (its separate provisions) has been applied.

Also, in the aspect of characteristics of the changes in the powers of the Constitutional Court of Ukraine, attention should be paid to the exclusion of such powers of the Constitutional Court of Ukraine as official interpretation of the laws. Formally, this authority has not yet been transferred to another entity. However, it is obvious that in this case there are prospects of securing an authentic interpretation of the laws that will be carried out by the body which legislates, that is, by the parliament.

The problem in Ukraine is that despite the fact that the changes to the Constitution of Ukraine in the part of justice were made back in June 2016 (and the norms of the Constitution of Ukraine, in accordance with its Article 8 are the norms of direct action), the Law 'On the Constitutional The Court of Ukraine' was adopted in July 2017. However, as of today none of the constitutional complaints submitted to the Constitutional Court of Ukraine has been considered. ${ }^{46}$ At the same time, a positive phenomenon is the introduction of a new power of the Constitutional Court of Ukraine in the part of verification on compliance with the Constitution of Ukraine (constitutionality) of questions that are proposed to be put for the all-Ukrainian referendum on people's initiative. Entities entitled to appeal to the Constitutional Court of Ukraine in this category of case include the President of Ukraine or not less than forty-five People's Deputies of Ukraine (which equals 1/10 of the composition of the parliament of Ukraine). Earlier, the authority to verify the constitutionality of such issues was secured by the Central Election Commission (since 2012, when the new Law of Ukraine 'On All-Ukrainian Referendum'47 came into force). However, such a provision was actively criticized, as the Central Election Commission is not a body entrusted with a professional resource for a competent assessment of this category of cases. Opinion No. 13 (2010) of the Consultative Council of European Judges to the attention of the Committee of Ministers of the Council of Europe on the role of judges in the enforcement of judicial decisions emphasizes that judicial independence and the right to a fair trial is in vain if the decision is not enforced. ${ }^{48}$ That is why, from the point of view of ensuring the effectiveness of the implementation of the decisions of the Constitutional Court of Ukraine, amendments to all the procedural codes of Ukraine (which took place in connection with their updating in the end of 2017 in the form of adoption in a new wording) are important, especially the following provisions: 1)

46 As of the end of January 2018, 503 constitutional complaints were received by the Constitutional Court of Ukraine, see <http://www.ccu.gov.ua/novyna/konstytuciyni-skargy-shcho-nadiyshly-dokonstytuciynogo-sudu-ukrayiny-za-stanom-na-29-sichnya> accessed 5 May 2019.

47 Zakon Ukrayini Pro vseukrayins'kiy referendum (the Law of Ukraine 'On All-Ukrainian Referendum') <http://zakon.rada.gov.ua/laws/show/5475-17http://zakon.rada.gov.ua/laws/show/5475-17> accessed 5 May 2019.

48 Opinion No. 13 (2010) of the Consultative Council of European Judges to the attention of the Committee of Ministers of the Council of Europe on the role of judges in the enforcement of judicial decisions < http://www.vru.gov.ua/content/file/Opinion_1-18.pdf > accessed 5 May 2019. 
established by the Constitutional Court of Ukraine unconstitutionality (constitutionality) of a law, another legal act or a separate provision applied (not applied) by the court in the decision of the case, if the court decision has not yet been executed, is the basis for review of court decisions in connection with exceptional circumstances in the administrative process (Part 5 of Article 361 of the Code of Administrative Proceedings of Ukraine ${ }^{49}$ ), as well as in civil process (paragraph 1, Part3, Article 423 of the Civil Procedural Code of Ukraine ${ }^{50}$ ) and economic process (paragraph 1, Part, Article 320 of the Commercial Procedural Code of Ukraine $\left.{ }^{51}\right)$; 2) established by the Constitutional Court of Ukraine unconstitutionality, constitutionality of a law, other legal act or their separate provision, applied by the court in resolving the case, is the exclusive circumstance in which court decisions which have come in effect can be reviewed in a criminal proceeding (paragraph 1, Part 3, Article 459 of the Criminal Procedural Code of Ukraine ${ }^{52}$ ).

\subsubsection{Financial Aspect of the Independence of the Constitutional Court of Ukraine}

According to Article 48 of the Law of Ukraine 'On the Constitutional Court of Ukraine', expenditures to provide financial support for the operations of the Court shall represent a separate line in the State Budget of Ukraine. Expenditures to provide financial support for the operations of the Court may not be reduced in the current fiscal year. The number of expenditures to provide financial support for the operations of the Court in the following year may not be less than the amount of the expenditures in the previous fiscal year. The Court shall, in compliance with the Budget Code of Ukraine, act as a chief administrator of funds from the State Budget of Ukraine as regards financial support for its operations.

According to expert estimates, in 2016, with the amount of financing of the Constitutional Court of Ukraine of 99.9 million UAH, cash expenses amounted to 99.1 million UAH, or 99.2\% of the annual plan. In 2016, the Constitutional Court of Ukraine held 329 sessions and plenary sessions, exceeding the planned number by 59. 120 sessions of the judges' panels were held while 132 were planned, during which 68 decisions were made, which is 3 decisions more than expected. In 2017, it was planned to consider and adopt 128 acts of the Constitutional Court of Ukraine (conclusions, decisions, resolutions), and 69 resolutions of the Boards of Judges of the Constitutional Court of Ukraine. Also, in 2017, additional UAH 2 million was required to be paid in response to the claims of judges of the Constitutional Court of Ukraine in retirement; otherwise, these payments would be compulsorily charged at the expense of the renumeration fund of employees and judges of the Constitutional Court of Ukraine. However, according to expert estimates, the indicators of performance specified in

49 Kodeks administrativnogo sudochinstva Ukrayini v redaktsiyi zakonu vid 03 jovtnia 2017 r. (The Code of Administrative Proceedings of Ukraine in the wording of 03 October 2017) <http://zakon.rada.gov. ua/laws/show/2747-15> accessed 5 May 2019.

50 Tsivil'niy protsesual'niy kodeks Ukrayini vid 18 beres'nia 2004 r., zi zminami (The Civil Procedure Code of Ukraine 18 March 2004 with changes) <http://zakon.rada.gov.ua/laws/show/1618-15> accessed 5 May 2019.

51 Gospodars'kiy protsesual'niy kodeks Ukrayini v redaktsiyi vid 15 groudnia 2017 r. (The Commercial Procedure Code of Ukraine in the wording of 15 December 2017) <http://zakon.rada.gov.ua/laws/ show/1798-12> accessed 5 May 2019.

52 Kriminal'niy protsesual'niy kodeks Ukrayini vid 13 kvitnia 2012 r., zi zminami (The Criminal Procedure Code of Ukraine 13 April 2012 with changes) <http://zakon.rada.gov.ua/laws/show/4651-17> accessed 5 May 2019. 
the passport of the budget program do not meet the criteria of realism, relevance and social significance in accordance with the Order of the Ministry of Finance of Ukraine No. 1536 'On Performance Indicators of the Budget Program' of 10 December 2010, registered in the Ministry of Justice of Ukraine on 27 December 2010 under №1353/18648. Most of the performance indicators of the budget program are descriptive and cost-oriented and are not focused on achieving strategic priorities and do not provide an opportunity to evaluate the effectiveness of the budget program. ${ }^{53}$ The real quantitative indicators of the Constitutional Court of Ukraine activity in 2017 are: 3 decisions, no (!) opinions and 42 court resolutions. ${ }^{54}$ This state of affairs is mostly due to the crisis within the Constitutional Court itself, which manifests itself, in particular, in the inability of the Court to elect a new head of the Constitutional Court of Ukraine. ${ }^{55}$

\subsection{STATUS OF THE SUPREME COURT AND COURTS}

\subsubsection{Statutory Aspect of the Independence of the Supreme Court and Courts of General Jurisdiction}

Let us take a look at constitutional backgrounds of the organization of the Ukrainian judiciary. Thus, Article 125 of the Constitution of Ukraine stipulates that the system of courts in Ukraine is formed in accordance with the territorial principle and the principle of specialisation and is defined by the law. Court shall be created, reorganized or dissolved on the basis of a law, the draft of which is issued to the Verkhovna Rada of Ukraine by the President of Ukraine after consultation with the High Council of Justice. The Supreme Court is the highest judicial body in the system of courts of Ukraine. According to the law, high specialized courts may also operate. Administrative courts act with the aim of protection of rights, freedoms and interests of a person in the sphere of public relations. The creation of extraordinary and special courts is not permitted.

The Law of Ukraine 'On the Judiciary and the Status of Judges' of 02 June 2016 (with amendments) defines the organization of judicial power and the administration of justice in Ukraine, which operates based on the rule of law according to European standards and ensures the right of everyone to a fair trial.

According to the abovementioned Law, the composition of the Supreme Court includes: 1) Grand Chamber of the Supreme Court; 2) Administrative Cassation

$53 \quad$ Financial and Economic Analysis Office in the Verkhovna Rada of Ukraine, 'Information note on the financing of the Constitutional Court of Ukraine in 2016-2020', September $2017<$ https://feao.org.ua/ wp-content/uploads/2017/10/17.10.2017_Constitusion_judge_1_\%D0\%9C\%D0\%94.pdf> accessed 6 May 2019.

54 The Constitutional Court of Ukraine in numbers for the period from 01 January 2017 to 31 December 2017 <http://www.ccu.gov.ua/publikaciya/konstytuciynyy-sud-ukrayiny-u-cyfrah>accessed 6 May 2019.

55 Thus, the three-year term of office of the chairman of the Constitutional Court of Ukraine Yuriy Baulin was terminated on 19 March 2017, since then the post of the court chairman is vacant. However, until a new court chairman is elected, Baulin continues to lead the court as an elderly judge. On 18 May, the Constitutional Court was unable to elect its head. The next voting was scheduled for 2 November, but the head of the Constitutional Court of Ukraine also was not elected on that day. According to the court rules, the head of the Constitutional Court of Ukraine should have been elected not later than two months before this post was vacant, that is, it should have taken place in early 2017. On 12 December 2017, the court was again unable to elect a new chairman in the absence of candidates. See: <https://p. dw.com/p/2pFAP> accessed 6 May 2019. 
Court; 3) Commercial Cassation Court; 4) Criminal Cassation Court; and 5) Civil Cassation Court.

In general, the Law reflects the new structure, introduced by the amendments to the Constitution of 2016 which provide for the transition from a four-level system (including courts of first and second instances, high (specialized) appellate courts and the Supreme Court of Ukraine) to a three-level system (which now includes courts of first and second instances and the Supreme Court with integrated specialized cassation courts).

\subsubsection{Functional Aspect of the Independence of the Supreme Court and Courts of General Jurisdiction}

Addressing the functional aspect of the characteristic of the Supreme Court independence, it is worth noting that an important criterion of judicial independence is not only the existence of legal guarantees of it, but also the perception of this power as independent by public; in other words, the attitude of public towards the judiciary and their perception of the judiciary as independent are very important factors of judicial independence. Thus, among the markers of sufficient constitutional and legal guarantees of judicial independence there are such questions as: Is the judiciary perceived as independent? What is the public's perception of possible political influences or manipulations in the appointment and promotion of the judges, as well as on their decisions in individual cases? ${ }^{56}$

According to Opinion No. 11 of the Consultative Council of European Judges to the Attention of the Committee of Ministers of the Council of Europe on the Quality of Judicial Decisions of 18 December 2008, ${ }^{57}$ legal certainty guarantees the predictability of the content and application of the legal rules, thus contributing in ensuring a high quality judicial system (paragraph 47). Judicial procedure must be clear, transparent and predictable (paragraph g of Main Conclusions and Recommendations).

According to Recommendation No.R (95) 5 of the Committee of Ministers to Member States concerning the Introduction and Improvement of the Functioning of Appeal Systems and Procedures in Civil and Commercial Cases, ${ }^{58}$ appeals to the third court should be used in particular in cases which merit a third judicial review, for example cases which would develop the law or which would contribute to the uniform interpretation of the law. They might also be limited to appeals where the case concerns a point of law of general public importance. The appellant should be required to state his reasons why the case would contribute to such aims (Article 7).

In this context, it is noted that many OSCE participating States have systems in which a single supreme court is the ultimate arbiter on matters pertaining to the various branches of the law (criminal, civil, or administrative), including the United Kingdom (with some exceptions), Denmark, and the United States. It is understandable that

$\overline{56}$ Rule of Law Checklist, <http://newjustice.org.ua/wp-content/uploads/2017/09/Rule_of_Law_ Checklist_UKR.pdf> accessed 6 May 2019.

57 CCJE, 'Opinion No 11 on the quality of judicial decisions' <http://www.vru.gov.ua/content/file/ Opinion_1-18.pdf> accessed 6 May 2019.

58 Recomendation R (95) 5 of the Committee of Ministers to Member States concerning the introduction and improvement of the functioning of appeal systems and procedures in civil and commercial cases <http://zakon5.rada.gov.ua/laws/show/994_153> accessed 6 May 2019. 
the Ukrainian legislator has sought to impose a degree of unity in jurisprudence by merging the cassation courts and creating a Grand Chamber to resolve potential disparities in jurisprudence between the 'Courts' within the new Supreme Court. The Grand Chamber should have adequate competencies to resolve genuine jurisprudential disparities between the cassation courts within the Supreme Court. To avoid a fourth instance jurisdiction and at the same time ensure that jurisprudential unity can be achieved and then maintained, the Law and any procedural laws adopted to implement it could specify that appeals to the Grand Chamber should be limited to cases involving matters of principle or particular public importance, or where a gross injustice is caused to the petitioner. ${ }^{59}$

With regard to that, in the scope of this research it is worth to emphasize the authority of the Supreme Court to ensure equal use of legal norms by courts of different specializations in the way and order stipulated by the procedural law.

Thus, according to parts 5, 6, Article 13 of the Law of Ukraine on 'On the Judiciary and Status of Judges', conclusions regarding application of the law provisions specified in resolutions of the Supreme Court of Ukraine shall be mandatory for all government entities that use in their activity a legal act containing the respective legal provision. Conclusion regarding application of the law provisions specified in resolutions of the Supreme Court of Ukraine shall be taken into account by other courts in the application of such legal provisions.

This novelty was positively assessed by the Venice Commission, which noted that it seems to be a good solution in a system which while lacking a doctrine of binding precedents nevertheless seeks to provide for a consistent approach to legal interpretation. ${ }^{60}$

In civil law countries, court rulings, especially of a supreme court, have a wider importance than in the specific case in respect of which that ruling was given and, from this perspective, it can be considered a source of law (paragraph 13). Numerous supreme courts in civil law countries are now empowered to select cases with intention of setting standards that should be applicable in future cases. Therefore, in these cases, already one judgment of a supreme court, when it was reached with intention to set a precedent, can count as an authoritative case law (paragraph 14). The Supreme Court must ensure uniformity of the case law so as to rectify inconsistencies and thus maintain public confidence in the judicial system (paragraph 20). ${ }^{61}$

Thus, for instance, according to Article 290 of the Code of Administrative Procedure of Ukraine, if one or several administrative courts have typical administrative cases in their proceedings, and the number of such cases defines the expediency of making a model

59 OSCE, ODIHR, 'Opinion on the Law of Ukraine "On he Judiciary and Status of Judges"' No JUDUKR/298/2017 [RJU/AT] <http://rsu.gov.ua/uploads/news/zusudoustriyvisnovokosce-d88675ed06. pdf> accessed 6 May 2019.

60 Joint opinion by the Venice Commission and the Directorate of Human Rights of the Directorate General of Human Rights and the Rule of Law on the Law 'On the Judiciary and the Status of Judges' and amendments to the Law on the High Council of Justice of Ukraine, adopted by the Venice Commission at its 102nd Plenary Session (Venice, 20-21 March 2015) <http://www.scourt.gov.ua/clients/vsu/vsu. nsf/(documents)/229B826C8AC787DEC2257D87004987C3> accessed 6 May 2019.

61 CCJE, 'Opinion No 20 on role of courts with respect to the uniform application of the law', Strasbourg, 10 November $2017<\mathrm{https} / / \mathrm{rm}$.coe.int/opinion-no-20-2017-on-the-role-of-courts-with-respect-tothe-uniform-a/16807661e3> accessed 6 May 2019. 
decision, a court which tries one or more of such cases can apply to the Supreme Court with a submission to try one of the cases by the Supreme Court as court of first instance.

\subsection{STATUS OF THE HIGH COUNCIL OF JUSTICE}

\subsubsection{Statutory aspect of the independence of the High Council of Justice}

The High Council of Justice consists of twenty one members: ten of them shall be elected by the Congress of Judges of Ukraine among judges or retired judges; two of them shall be appointed by the President of Ukraine; two of them shall be elected by the Verkhovna Rada of Ukraine; two of them shall be elected by the Congress of Advocates of Ukraine; two of them shall be elected by the All-Ukrainian Conference of Public Prosecutors; two of them shall be elected by the Congress of Representatives of Law Schools and Law Academic Institutions.

The Law of Ukraine 'On the High Council of Justice' of 21 December 2016 governs the status, powers, principles of organisation, and the procedures of the High Council of Justice.

The Consultative Council of European Judges (hereinafter - the CCJE) considered that the European Charter - in so far as it advocated the intervention (in a sense wide enough to include an opinion, recommendation or proposal as well as an actual decision) of an independent authority with substantial judicial representation chosen democratically by other judges - goes to a general direction which the CCJE had wished to commend. This is particularly important for countries which do not have other long-entrenched and democratically proved systems. ${ }^{62}$ Thus, the existence of the High Council of Justice is important, in particular, from the point of view of guaranteeing the judicial independence according to the international standards in this sphere.

As of today, most European States have introduced a body independent of the executive and legislature with an exclusive or lesser role in respect of appointments and (where relevant) promotions; examples are Andorra, Belgium, Cyprus, Denmark, Estonia, Finland, France, Iceland, Ireland, Italy, Lithuania, Moldova, Netherlands, Norway, Poland, Romania, Russia, Slovakia, Slovenia, 'the Former Yugoslav Republic of Macedonia' and Turkey. ${ }^{63}$

It is worth pointing out that for Ukraine, as for the country with unstable democracy, it is important that the High Council of Justice shall be one of the segments of the mechanism providing for an independent judiciary; however, the Council itself shall be independent and 'protected', including the mechanisms of 'restraint and counterbalance', from the influence of the legislative and the executive branches of power, and from the head of state.

62 Recomendation No. R (94) 12.

63 CCJE, 'Opinion No 1 on standards concerning the independence of the judiciary and the irremovability of judges' <http://www.vru.gov.ua/content/file/Opinion_1-18.pdf> accessed 6 May 2019. 


\section{CONCLUDING REMARKS}

It is obvious that every democratically elected government has the right to introduce reforms in different spheres of the State's activities. When the reform was promised during the elections, it is even a moral obligation to fulfil the promise.

Nevertheless, the government's power in this field is not unlimited. The limits are stated in the Constitution. Yet in Europe, the limits also stem from the standards worked out by the European community; standards which are results of discussions, compromises and different experience of European countries. Poland, as EU Member State, has to fulfil the standards of both the Council of Europe and the European Union. The Council of Europe standards regarding the judiciary may be found in the opinions, positions, statements etc. of Consultative Council of European Judges and Venice Commission, while EU standards are shown in the European Network of Councils of Judiciary works.

When comparing those standards to the recently introduced changes in the Polish legal system regarding the judiciary it seems that there are a lot of legislative changes introduced which are in breach of the European standards, according to the various European bodies. This may lead to many problems with relation to the functioning of the Polish courts and judges, e.g. courts of other EU Member States may refuse to perceive the Polish judiciary as independent, thus not applying the principle of mutual trust (see the decision of an Irish court refusing to execute the European Arrest Warrant on a Polish citizen). As a result, judgments of Polish courts might not be automatically executed in other European countries.

There is still hope, though, that those changes which go against the European standards of judicial independence will be reversed and that the Polish judiciary will not lose the guarantees of its independence. We must remember that all rights and freedoms guaranteed in the European Convention of Human Rights, as well as in the Constitution of the Republic of Poland will be of purely illusory nature if the right to fair trial is not guaranteed, and that the fair trial as such is not possible without judiciary which is institutionally independent from other branches of state power.

It is obvious that the changes which have happened in Ukraine in connection with the beginning of large-scale judicial reform implementation are generally positive and progressive. However, assessing the respective results of the reform we should consider that the legal part of the reform is only one of its constituents and thus, successful realization of all statements on the reformation of the judiciary status is possible only if the complex nature of these processes as well as political, social, economical, historical and other factors are taken into account.

Speaking about key aspects in need of attention and improvement, it is worth mentioning the following: 1) in the part of legal regulation of the status of Constitutional Court of Ukraine, the renovation of the system of legal acts regulating the organization and operation of the Constitutional Court of Ukraine should be improved and completed. In particular, the Rules of Procedure of the Constitutional Court of Ukraine should be adopted. However, the absence of the latter document should not be a reason for a body of constitutional jurisdiction not to fulfill their powers (as it happens today in the part of considering constitutional complaints), because the norms of the Constitution of Ukraine are direct-acting and their realization is possible in the absence of legislative and subordinate regulatory acts; 2) a gap which can potentially cause a constitutional 
conflict needs legal regulation: the point is that the mechanism of influence on subjects who form the Constitutional Court of Ukraine in case of their inaction in the matter should be secured; 3 ) it is reasonable to extend the institute of constitutional complaint on subjects of local self-government; 4) it is necessary to activate the operation of the Supreme Court in the part of making model decisions; 5) the legal regulation of the mechanisms of interaction between the parliament, the President of Ukraine and the High Council of Justice, in particular, in the part of participation of the latter in the formation of legislation concerning legal proceedings and financing of the judiciary should be improved. 